\title{
Viral-Like Symptoms Induced by the Ectopic Expression of the p23 Gene of Citrus tristeza virus Are Citrus Specific and Do Not Correlate with the Pathogenicity of the Virus Strain
}

\author{
Carmen Fagoaga, ${ }^{1}$ Carmelo López, ${ }^{2}$ Pedro Moreno, ${ }^{1}$ Luis Navarro, ${ }^{1}$ Ricardo Flores, ${ }^{2}$ and \\ Leandro Peña ${ }^{1}$ \\ ${ }^{1}$ Instituto Valenciano de Investigaciones Agrarias (IVIA), Apdo. Oficial, Moncada 46113, Valencia, Spain; ${ }^{2}$ Instituto de \\ Biología Molecular y Celular de Plantas (UPV-CSIC), Universidad Politécnica de Valencia, Avenida de los Naranjos, \\ Valencia 46022, Spain
}

Submitted 25 October 2004. Accepted 10 January 2005.

Ectopic expression of the $p 23$ gene from a severe (T36) strain of Citrus tristeza virus (CTV) induces viral-like symptoms in Mexican lime. Here, we report that expressing the same gene from a mild strain induced similar symptoms that correlated with accumulation of p23 protein irrespective of the source strain. CTV inoculation of transgenic limes showing CTV-like leaf symptoms and high p23 accumulation did not modify symptoms initially, with the virus titer being as in inoculated nontransgenic controls; however, at later stages, symptoms became attenuated. Transformation with p23-T36 of CTV-susceptible sweet and sour orange and CTV-resistant trifoliate orange also led to CTV-like leaf symptoms that did not develop when plants were transformed with a truncated $p 23$ version. In transgenic citrus species and relatives other than Mexican lime, p23 was barely detectable, although symptom intensity correlated with levels of $p 23$ transcripts. The lower accumulation of p23 in sweet and sour orange compared with Mexican lime also was observed in nontransgenic plants inoculated with CTV, suggesting that minimal p23 levels cause deleterious effects in the first two species. Conversely, transgenic expression of $p 23$ in CTV nonhost Nicotiana spp. led to accumulation of p23 without phenotypic aberrations, indicating that p23 interferes with plant development only in citrus species and relatives.

Additional keywords: pathogenicity determinant, silencing suppressor.

Citrus tristeza virus (CTV), a member of the genus Closterovirus within the family Closteroviridae, is the causal agent of the most economically important viral disease of citrus. The virus is naturally restricted to citrus species and relatives, and only occurs in phloem-associated tissues (Bar-Joseph et al. 1989). CTV strains often differ by their biological characteristics, particularly the type and intensity of symptoms induced in distinct hosts (Roistacher and Moreno 1991). Some strains are essentially symptomless in most citrus varieties, but most incite

Corresponding author: L. Peña; Telephone: 34-96-3424000; Fax: 34-963424001; E-mail: 1penya@ivia.es

C. Fagoaga and C. López contributed equally to this work. severe phenotypes that include i) decline and death of cultivars, except lemon (Citrus limon (L.) Burm.), when grafted on sour orange (C. aurantium L.) rootstock; ii) stunting, stem pitting, low yield, and poor fruit quality regardless of the rootstock used, and iii) leaf yellowing and growth cessation of sour orange, lemon, and grapefruit (C. paradisi Macf.) seedlings, a syndrome called seedling yellows (Fraser 1952).

Some species, such as Mexican lime $(C$. aurantifolia (Christm.) Swingle), are very sensitive and show symptoms upon infection with most CTV strains, whereas others, such as grapefruit and sweet orange (C. sinensis (L.) Osbeck), are affected only by severe strains. Although sour orange is sensitive as a rootstock, seedlings accumulate virus at low titer with most CTV isolates. General resistance to CTV has been observed in trifoliate orange (Poncirus trifoliata (L.) Raf.) (Yang et al. 2003; Yoshida 1996), and resistance to some isolates occurs in pummelo (C. grandis [L.] Osbeck) (Fang and Roose 1999; Garnsey et al. 1996) and kumquat (Fortunella crassifolia Swingle) (Mestre et al. 1997).

CTV virions are flexuous filaments of $2,000 \times 11 \mathrm{~nm}$ in size, with two capsid proteins of 25 and $27 \mathrm{kDa}$ (p25 and p27, respectively), coating 95 and $5 \%$ of the particle length, respectively (Febres et al. 1996). The genome is a singlestranded positive-sense RNA of approximately $20 \mathrm{~kb}$ that contains 12 open reading frames (ORFs) and 5'- and 3'-terminal untranslated regions (UTRs) (Karasev et al. 1995). The 25 '-proximal ORFs encode replication-related proteins that are translated directly from the genomic RNA, whereas the 10 3'-proximal ORFs encode proteins p33, p6, p65, p61, p27, p25, p18, p13, p20, and p23, which are expressed via 3'-coterminal subgenomic ( $\mathrm{sg}$ )RNAs. The small hydrophobic p6 is proposed to act as a membrane anchor; p65 is a homologue of HSP70 heat-shock proteins and, together with p61, p25, and p27, is involved in virion assembly (Satyanarayana et al. 2000). Recently, p27 has been shown to initiate encapsidation from the $5^{\prime}$ end of the genomic RNA (Satyanarayana et al. 2004). The p20 protein accumulates in amorphous inclusion bodies of CTV-infected cells (Gowda et al. 2000) and might be a pathogenicity factor because it has silencing suppressor activity in Nicotiana benthamiana and N. tabacum (Lu et al. 2004; Reed et al. 2003). The function of p33, p13, and 18 presently is unknown.

The only CTV protein with no homologue in other closteroviruses is $\mathrm{p} 23$. In citrus protoplasts, its sgRNA is the most 
abundant at the beginning of the infection and the second most prevalent in later stages, suggesting a role of p23 in early steps of viral replication or transcription (Hilf et al. 1995; Navas-Castillo et al. 1997). However, p23 accumulates at low levels in citrus-infected plants (Pappu et al. 1997). In vitro, p23 has the ability to bind RNA in a non-sequence-specific manner, and mutations affecting the cysteine and histidine residues of a zinc finger domain conserved in different isolates increase the dissociation constant of the p23-RNA complex (López et al. 2000). Additionally, p23 is involved in regulating the synthesis of plus and minus strands during RNA replication, with the zinc finger domain and an adjacent basic region being indispensable for asymmetrical accumulation of the plus strand (Satyanarayana et al. 2002). Furthermore, transgenic Mexican lime plants constitutively expressing p23 of the severe CTV strain T36 display alterations resembling the symptoms induced by CTV in this host, with their intensity being associated with p23 accumulation (Ghorbel et al. 2001). This strongly suggests that this protein is an important pathogenicity factor, a view supported by recent experiments showing that $\mathrm{p} 23$ is a potent suppressor of local silencing in N. tabacum (Lu et al. 2004).

To gain a deeper insight into the role of p23 on CTV pathogenesis, a first aim of this work was to determine whether ectopic expression of the $p 23$ gene from a severe and a mild CTV strain induced similar phenotypic effects on Mexican lime-a question that, to our knowledge, remains to be addressed for most plant-virus systems - and whether the symptoms related to $\mathrm{p} 23$ accumulation. As a second aim, we examined whether the effects of expressing the $p 23$ gene were specific to citrus species and relatives and, among them, whether differences could be observed between species susceptible and resistant to CTV. Our results show that p23 accumulation, irrespective of the source strain, is the main factor governing the intensity of CTV-like symptoms, which are expressed by citrus species and relatives susceptible or resistant to CTV but not by nonhosts $N$. tabacum and $N$. benthamiana.

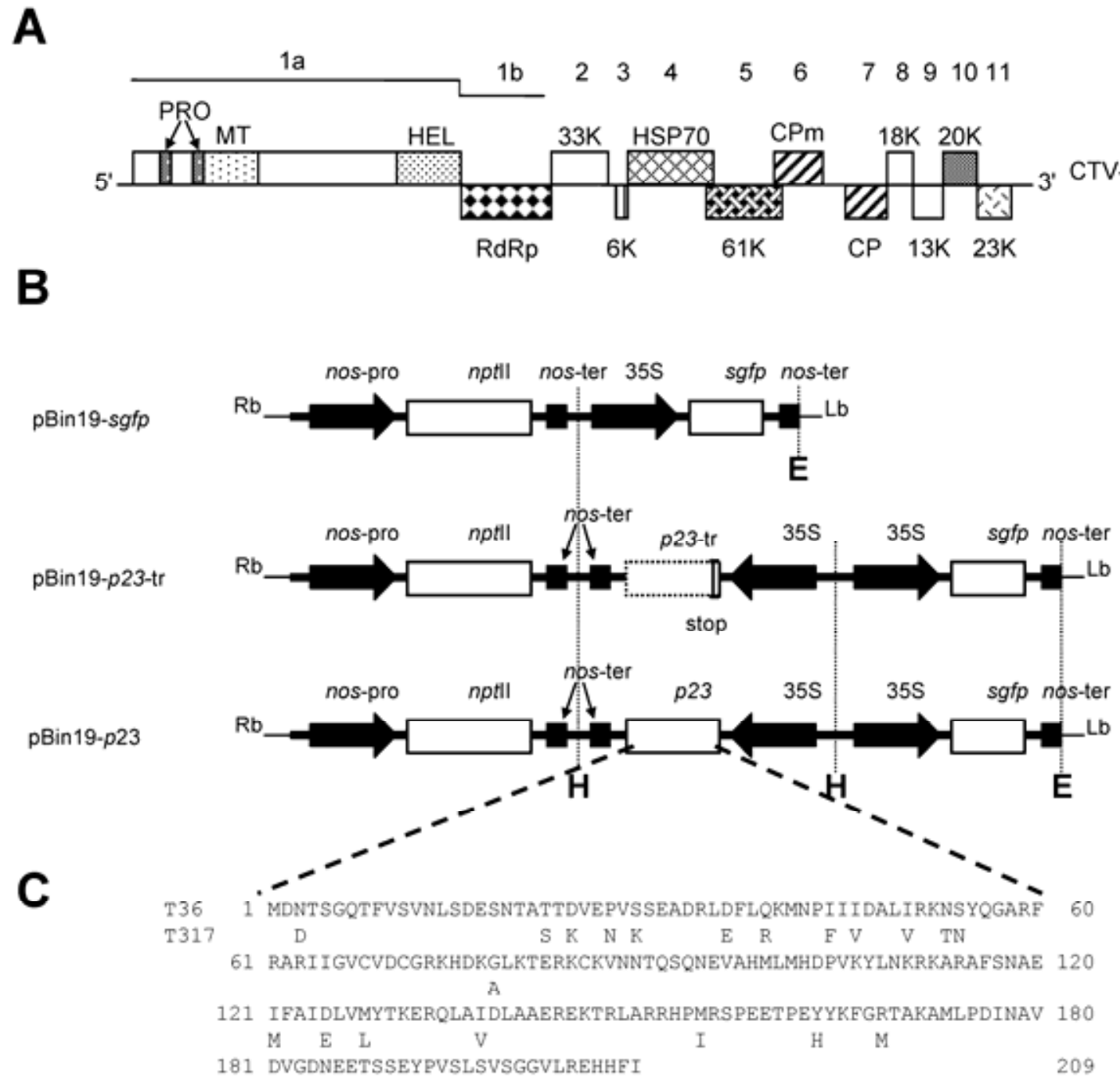

Fig. 1. Schematic representation of the Citrus tristeza virus (CTV) genome, gene constructs, and p23 amino acid sequences. A, Open reading frames (ORFs) in the genomic CTV RNA. The 5' ORFs 1a and 1b produce a fusion protein with two papain-like protease (PRO), plus methyltransferase (MT), helicase (HEL), and RNA-dependent RNA polymerase (RdRp) domains. The 10 ORFs of the 3' half of the genome encode a 6-kDa hydrophobic protein, a 65-kDa homologue of the HSP70 heat-shock proteins, the 25- and 27-kDa major and minor coat proteins (CP and CPm, respectively), and other proteins of 33, 61, $18,13,20$, and $23 \mathrm{kDa}$. B, Diagram of the T-DNA from the binary vector pBin19-sgfp and constructs designed to express the wild-type ( $p 23$ ) and truncated ( $p 23$-tr) genes controlled by the doubly enhanced Cauliflower mosaic virus (CaMV) $35 \mathrm{~S}$ promoter and the nopaline synthase terminator (nos-ter). The $p 23$ and p23-tr cassettes are flanked by the neomycin phosphotransferase II gene (nptII) between the nos promoter (nos-pro) and the nos-ter, and by the synthetic green fluorescent protein gene ( $s g f p$ ) between the $35 \mathrm{~S}$ promoter and the nos-ter. HindIII and EcoRI restriction sites are indicated by $\mathrm{H}$ and E, respectively. C, Predicted amino acid sequences of p23 from CTV-T36 and -T317. 


\section{RESULTS}

Symptoms induced in Mexican lime by expressing the $p 23$ gene from a severe and a mild CTV strain are similar and correlate with p23 accumulation.

In a previous study, transgenic Mexican limes expressing the p23 gene from the severe strain T36 displayed vein clearing, leaf epinasty, stunting, and stem pitting similar to symptoms accompanying CTV infection, whereas plants carrying a truncated p23 version ( $p 23$-tr) were fully normal (Ghorbel et al. 2001). To explore whether the p23 source could influence symptom expression, Mexican limes were transformed with the $p 23$ gene from T317, a CTV strain that produces only mild vein clearing in young leaves. Transformation was performed with Agrobacterium tumefaciens harboring either an empty pBin19 vector or containing the $p 23-\mathrm{T} 317, p 23-\mathrm{T} 36$, or $p 23$-tr versions (Fig. 1). After 4 to 12 weeks, NPTII-resistant shoots positive for the expression of the green fluorescent protein (GFP) gene were regenerated, micrografted in vitro, and, sev- eral weeks later, side-grafted onto a vigorous rootstock in the greenhouse. In all, 20 transgenic lines with the p23-T317, 20 with the p23-T36, 10 with the p23-tr, and 10 with the empty vector were selected. Integration of the $p 23$-derived transgenes, or of the synthetic GFP ( $s g f p$ ) transgene in the case of the empty vector, was confirmed by polymerase chain reaction (PCR) amplification (results not shown). Southern blot analysis revealed integrations of one to more than five complete copies of the p23 transgene (Fig. 2A and B), and Northern blot analysis showed variable transgene expression depending on the line, with an inverse correlation being observed between the transgene copy number and mRNA expression (Fig. 2A and $\mathrm{C}$ ).

Soon after transfer to the greenhouse, five of the p23-T317 lines started showing severe developmental aberrations-leaf abscission, apical necrosis, and stem necrosis - and died several weeks later. The remaining p23-T317 lines showed CTVlike symptoms that ranged from mild vein clearing to leaf epinasty, apical necrosis, and stunting, except for two lines that

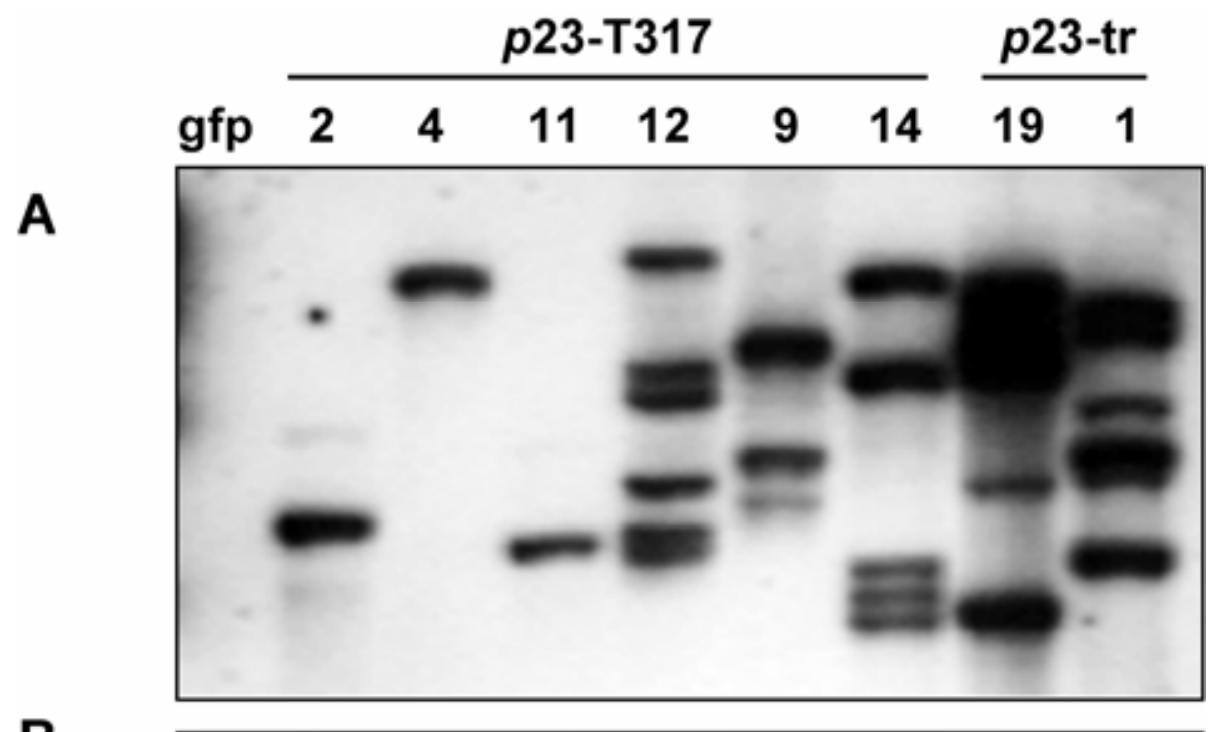

B

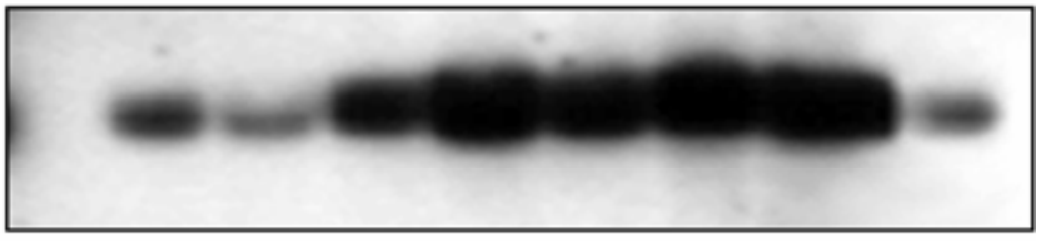

C

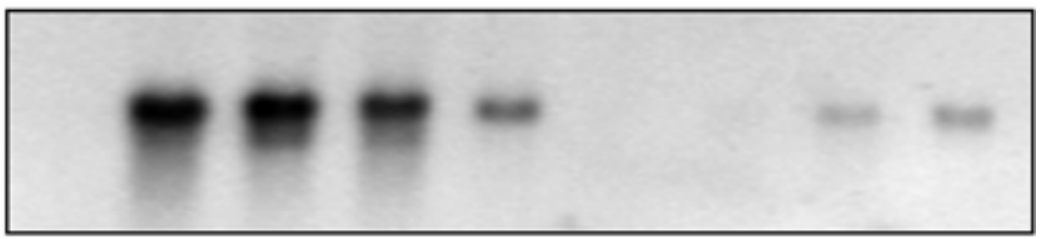

D

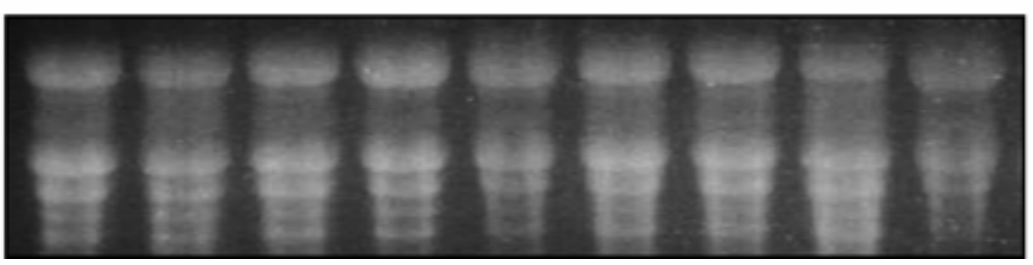

Fig. 2. Southern and Northern blot hybridization of nucleic acid preparations from lime plants transformed with the $p 23$-T317 gene (lanes 2,4 , 11, 12, 9, and 14), with a truncated version thereof, p23-tr (lanes 19 and 1), or with the vector pBin19-sgfp (lane gfp). DNA was digested with A, EcoRI, which cuts once the T-DNA near the left border, or with B, HindIII, which excises the expression cassette. C, Total RNA extracted from transgenic plants was separated by electrophoresis in a formaldehyde-containing agarose gel, and transferred to a nylon membrane. D, Ethidium bromide staining of the RNA gel showing that equivalent amounts of RNA were loaded in the different lanes. A, B, and $\mathbf{C}$, Membranes were probed with a digoxigenin-labeled fragment of the $p 23$ coding region. 
were symptomless. These symptoms were essentially similar to those observed in p23-T36 transgenic limes, as previously reported (Ghorbel et al. 2001) and in this work, whereas the phenotype of the lines carrying $p 23$-tr or the empty vector was visually normal (Fig. 3A; results not shown). Extracts from the transgenic plants did not react with a mixture of the monoclonal antibodies 3CA5 + 3DF1 against the CTV major coat protein, thus discarding accidental infection with CTV (results not shown).

The p23 protein accumulated in most transgenic limes carrying either $p 23-\mathrm{T} 36$ or $p 23-\mathrm{T} 317$, as revealed by reaction with the p23 antiserum in Western blots but not in plants carrying $p 23$-tr or the empty vector (Fig. 3B). More specifically, ac- cumulation of p23 (and of its mRNA) was positively correlated with the intensity of the CTV-like symptoms exhibited by the transgenic limes, irrespective of the pathogenicity characteristics of the CTV strain (T36 or T317) from which the $p 23$ gene was obtained (Ghorbel et al. 2001) (Figs. 2C and 3). This point is illustrated by lines $p 23-\mathrm{T} 36-3$ and -41 , which accumulated high levels of p23 from the severe strain and displayed prominent CTV-like symptoms, and by lines $p 23-\mathrm{T} 317-4$ and 11, which expressed similar symptoms and also accumulated high levels of p23 protein (Fig. 3) and of its mRNA (Fig. 2C) from the mild strain. Therefore, the accumulation of p23 rather than its origin seems to determine the intensity of the symptoms in transgenic limes.

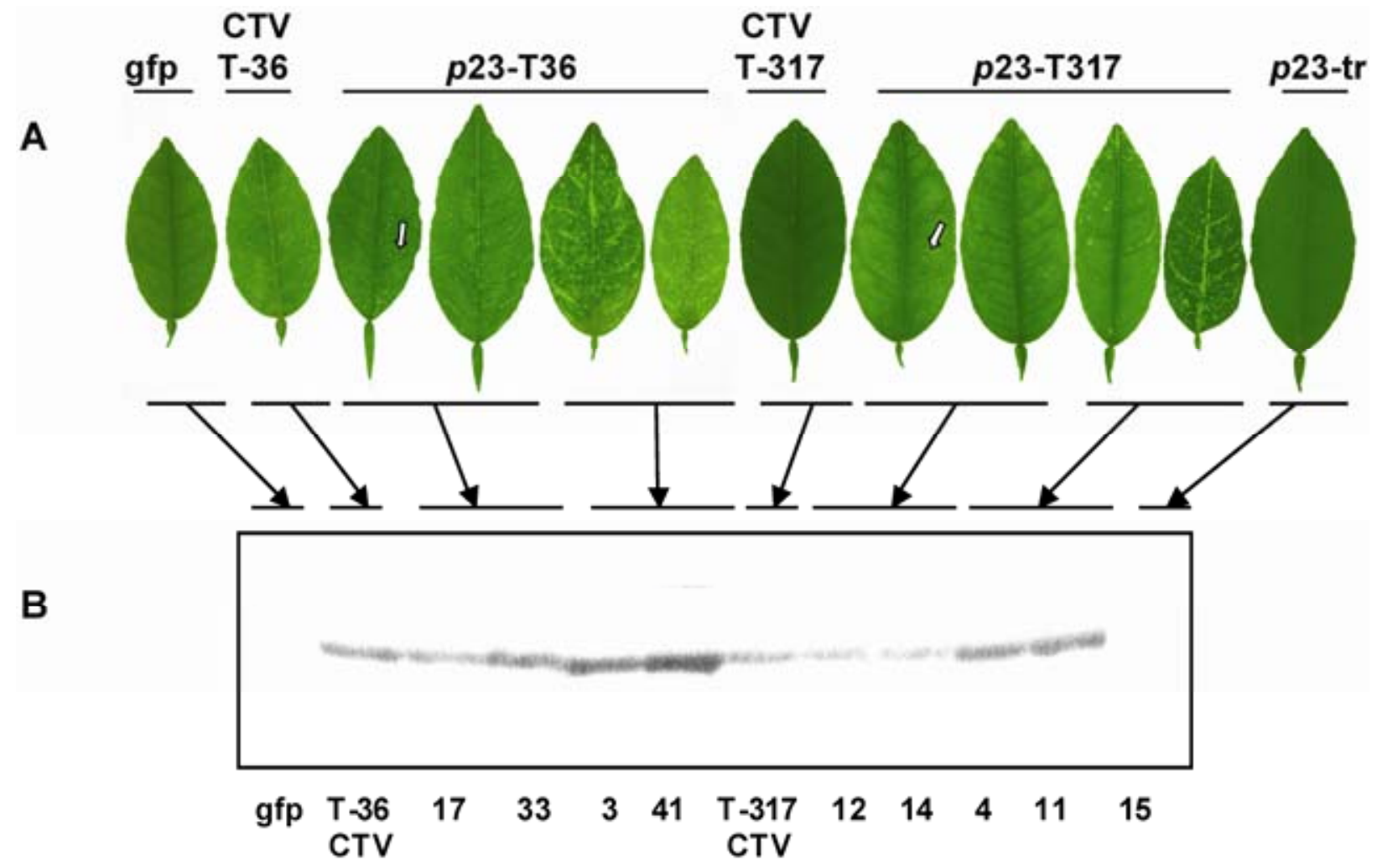

Fig. 3. Relationship between leaf symptoms in transgenic Mexican limes and accumulation of Citrus tristeza virus (CTV) p23 protein as revealed by Western-blot analysis. A, Leaf symptoms expressed by transgenic lines carrying the $p 23-\mathrm{T} 36, p 23-\mathrm{T} 317$, or $p 23$-tr constructs, and by nontransformed limes inoculated with either CTV-T36 or CTV-T317; gfp refers to a transgenic line carrying only the T-DNA from pBin19-sgfp vector. White arrows indicate vein clearing. B, Total proteins from transgenic plants were separated by electrophoresis in a sodium dodecyl sulfate polyacrylamide gel, transferred to a nitrocellulose membrane, and probed with a CTV p23 antiserum. Each lane was loaded with $20 \mu \mathrm{g}$ of total protein quantified by Bradford analysis. Numbers indicate the transgenic lines carrying p23 from CTV-T36, -T317, or a truncated version ( $p 23$-tr). CTV-T36 or CTV-T317 refers to nontransgenic limes infected with those isolates.

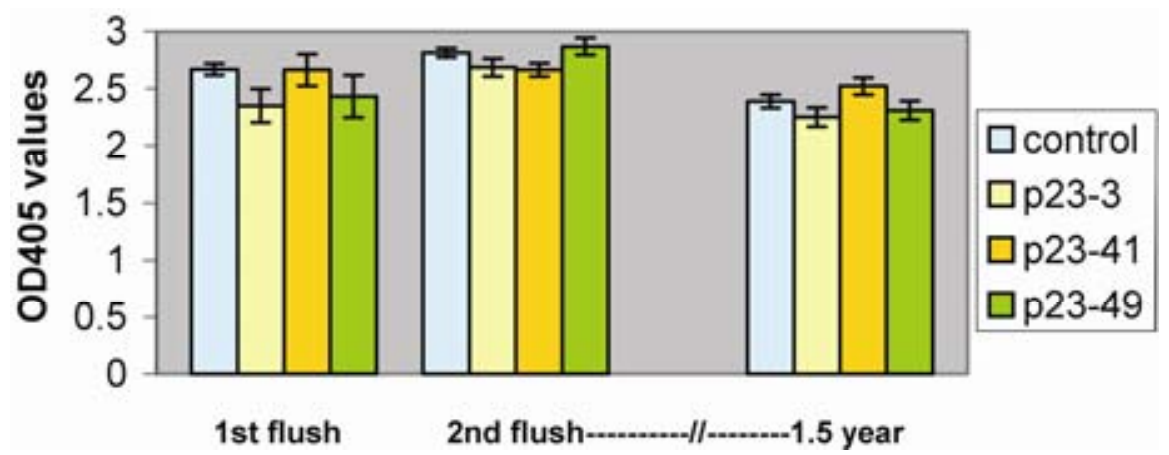

Fig. 4. Citrus tristeza virus titer in $p 23$-transgenic and control lime plants (transformed with the pBin19-sgfp vector) estimated by double-antibody sandwich enzyme-linked immunosorbent assay using the monoclonal antibodies 3DF1 + 3CA5. A pool of six to seven new leaves from each plant was assayed in the first and second flushes, and 1.5 years after inoculation. Each bar in the histogram represents the average \pm SE of four inoculated plants per transgenic line; OD405 = optical density at $405 \mathrm{~nm}$. 
CTV infection of transgenic Mexican limes expressing p23 leads to normal virus accumulation and symptoms.

To investigate whether CTV-like developmental aberrations incited by the constitutive expression of p23 could be modified by infecting the transgenic limes with CTV and whether CTV titer could be increased by overexpression of this protein which, at least in N. benthamiana and N. tabacum, is a silencing suppressor (Lu et al. 2004), four propagated plants from three $p 23$ T36 transgenic lines and a control line transformed with the empty vector were inoculated with a clonal strain of CTV-T36. These three lines were chosen because they contained a single copy of the $p 23$ transgene and showed conspicuous CTV-like leaf symptoms concurrent with high accumulation of p23. Leaf symptoms incited by this CTV strain on nontransgenic Mexican limes are similar, although usually less notorious than those shown by p23-transgenic plants, making it sometimes difficult to discriminate viral and transgene-induced alterations. However, CTV-T36 produces a characteristic leaf cupping in Mexican lime that was observed only occasionally in p23-transgenic limes.

CTV accumulation was estimated by semiquantitative doubleantibody sandwich enzyme-linked immunosorbent assay (DASELISA) in the first two flushes (within an approximate interval of 6 months after inoculation) and then 18 months after inocu- lation. Virus titer was similar in $p 23$ and control (empty vector) transgenic plants and remained essentially unchanged in the three flushes investigated (Fig. 4). In the first two, CTV infection did not cause any modification with respect to the CTVlike symptomatology exhibited by noninoculated $p 23$-transgenic plants, except for the presence of the leaf cupping associated with viral infection. However, the situation changed in successive flushes and, by 18 months after CTV inoculation, symptoms of $p 23$-transgenic plants became attenuated and appeared similar to those of empty vector-transgenic plants infected with CTV. This attenuation also was observed in noninoculated $p 23$-transgenic plants. Overall, these results confirmed previous observations that p23 accumulation, by itself, incites the CTV-like symptoms (Ghorbel et al. 2001), and also showed that, although at least in the early stages this phenotype was unaffected by the presence of CTV in the transgenic plants, it was influenced by their developmental stage.

CTV susceptible and resistant citrus species and relatives transformed with $p 23$ gene but not

with a truncated version also show CTV-like leaf symptoms.

To further elucidate the role of $\mathrm{p} 23$ as a pathogenicity factor, citrus species and relatives with different susceptibility to CTV
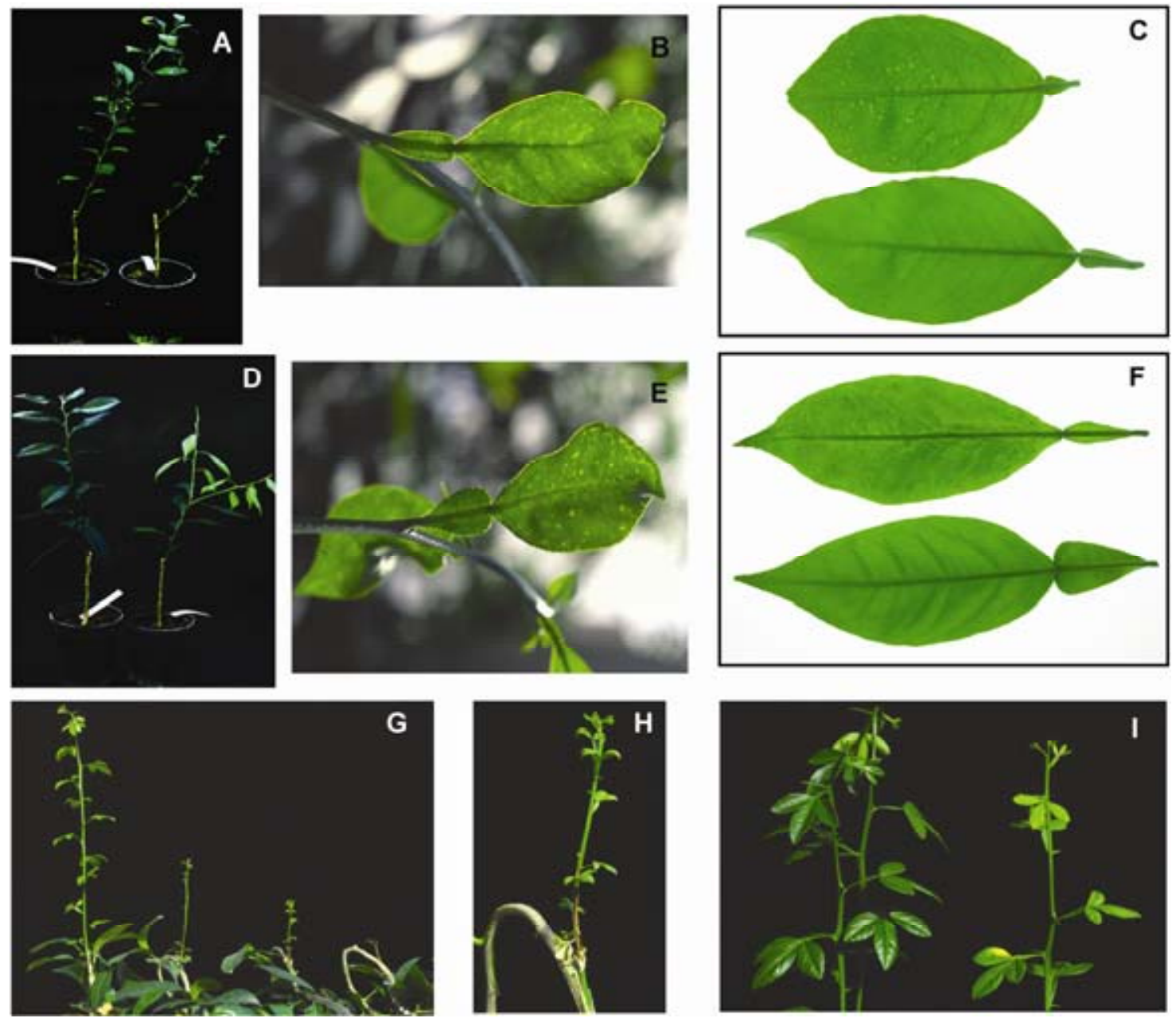

Fig. 5. Citrus tristeza virus (CTV)-like symptoms exhibited by $p 23$-transgenic $\mathbf{A}$ through $\mathbf{C}$, sweet, $\mathbf{D}$ through $\mathbf{F}$, sour, and $\mathbf{G}$ through $\mathbf{I}$, trifoliate orange plants grafted on a vigorous rootstock. A, A p23-sweet orange plant showing leaf distortion and stunting (right) compared with a $p 23$-tr control (left). B, Chlorosis and vein clearing in a leaf from a $p 23$-sweet orange plant. C, A malformed leaf from a $p 23$-sweet orange plant (top) compared with a normal leaf from a $p 23$-tr control (bottom). D, Leaf abscission and distortion in alternate flushes in a $p 23$-sour orange plant (right) compared with a $p 23$-tr control (left). $\mathbf{E}$, Vein clearing and chlorotic pinpoints in a $p 23$-sour orange leaf. F, A malformed leaf from a $p 23$-sour orange plant (top) compared with a normal leaf from a $p 23$-tr control (bottom). G, From left to right, a $p 23$-tr and three $p 23$-trifoliate orange plants with increasing developmental aberrations that include leaf abscission, stem necrosis, and stunting. H, Detail of stem necrosis in a $p 23$-trifoliate orange plant. I, Leaf chlorosis in a $p 23$-trifoliate orange (right) compared with a $p 23$-tr control plant (left). 
were transformed with the $p 23$ gene. Whereas Mexican lime is very sensitive to $\mathrm{CTV}$, sweet orange is susceptible but only shows symptoms when infected with severe strains, sour orange is susceptible to CTV strains that induce seedling yellows, and trifoliate orange is resistant to the virus because most CTV strains are unable to establish infections. More specifically, susceptibility of sweet orange cv. Pineapple and sour orange cv. Sevillano to CTV-T36 was confirmed by graft inoculation and analysis by DAS-ELISA and reverse-transcription (RT)PCR; although the first remained symptomless, the second showed seedling yellows (data not shown). Resistance of trifoliate orange cv. Burjasot to CTV-T36 also was confirmed by graft inoculation: DAS-ELISA and RT-PCR failed to detect the virus in samples taken at 6,12, and 24 months after inoculation. Furthermore, simple sequence repeat (SSR) markers associated with the CTV-resistance locus (provided by M. Roose) (Yang et al. 2003) showed heterozygosity for this region in trifoliate orange cv. Burjasot (data not shown).

Internodal stem segments of sweet orange cv. Pineapple and sour orange cv. Sevillano and epicotyl segments of trifoliate orange cv. Burjasot were transformed with A. tumefaciens carrying either the $p 23$-T36 or the $p 23$-tr version. Regeneration of transgenic shoots from sweet and sour orange occurred usually with low efficiency, particularly with p23-T36. Specifically, for sweet orange, 22 of $710(3.1 \%)$ explants transformed with p23-T36 and 47 of 350 (13.4\%) explants transformed with the p23-tr were PCR positive for the transgene. For sour orange, 11 of $1,600(0.7 \%)$ explants transformed with $p 23-\mathrm{T} 36$ and 6 of $200(3 \%)$ explants transformed with the p23-tr were PCR positive for the transgene. A similar trend was observed with trifoliate orange, although genetic transformation of this species was more efficient: 25 of 170 explants transformed with p23-tr were PCR positive for the transgene 1 month after regeneration, whereas a total of 25 of 230 explants transformed with $p 23$-T36 were PCR positive along the experiments. These results strongly suggest that $p 23$ integration and expression were toxic for these three species. This early effect of p23 during the in vitro culture stage was more prominent than that previously observed with Mexican lime (Ghorbel et al. 2001; this work).

In the greenhouse, after grafting transgenic plantlets onto vigorous rough lemon (C. jambhiri Lush) seedlings, 12 sweet orange, 5 sour orange, and 11 trifoliate orange lines carrying the $p 23$ transgene showed severe abnormalities: they did not sprout, became necrotic, and died several weeks later. Shoots from the surviving grafts exhibited CTV-like leaf symptoms and developmental aberrations of different severity depending on the transgenic line and citrus species (Fig. 5). The CTV-like phenotype observed in transgenic sour and sweet orange plants generally included vein clearing, epinasty, and stunting (Fig. $5 \mathrm{~A}$ through $\mathrm{F}$ ), which are produced in these species only by very severe CTV strains. Other aberrations, such as leaf distortion, apical necrosis, and leaf abscission, also were found (Fig. $5 \mathrm{~A}$ through $\mathrm{F}$ ). Interestingly, most $p 23$-transgenic plants showed either aberrations or normal phenotype in alternate growing flushes (Fig. 5D), suggesting a complex relationship between the transgene expression and the developmental stage. Two $p 23$-sweet orange plants exhibiting the most severe necrosis, leaf distortion, and stunting died after 2 years in the greenhouse. Transgenic $p 23$-trifoliate orange plants showed chlorosis, leaf abscission, stem necrosis, stunting, and apical necrosis (Fig. 5G through I), which caused the death of one 1-year-old plant. On the other hand, the $p 23$-tr transgenic plants of the three species were phenotypically normal and developed as the nontransgenic controls (Fig. 5).
Intensity of CTV-like leaf symptoms in citrus species other than Mexican lime correlates with levels of $p 23$ transcripts.

Integration and expression of p23 transgenes were confirmed in the three species by Southern and Northern blot analyses, respectively. The number of transgene copies was variable, ranging from one to eight (Fig. 6A and B), with levels of $p 23$ T36 and $p 23$-tr transcripts showing generally an inverse correlation with the number of copies (Fig. 6A through D). In plants harboring one or two copies of the transgene, the severity of the CTV-like leaf symptoms correlated generally with the accumulation of p23-transcripts (Fig. 6C and D; results not shown). However, Western blot analysis only revealed the presence of p23 in two sweet and one sour orange plants carrying one or two copies of $p 23$-T36 (Fig. 6E; data not shown).

To test whether the low or undetectable levels of p23 in transgenic plants paralleled those in nontransgenic CTV-infected plants, several citrus species with different susceptibility to CTV were inoculated with the severe strains T36 or T305. Whereas sensitive hosts, such as C. macrophylla, Mexican lime, and grapefruit, showed high to moderate accumulation of p23, the protein was barely detectable in sweet and sour orange (Fig. 6F). These results were reproduced with leaves at different developmental stages (data not shown). The parallelism found in the accumulation of p23 between p23-transgenic and CTVinfected nontransgenic Mexican lime (Fig. 2), and sweet and sour orange (Fig. 6E and F), suggests that the latter two species cannot accumulate p23 at high levels and that even minimal amounts of this protein cause deleterious effects in these two species.

\section{Transgenic expression of p23 in CTV nonhost Nicotiana spp. does not induce phenotypic aberrations.}

To investigate whether transgenic expression of $p 23$ was sufficient to produce developmental aberrations in other plants irrespective of their CTV host or nonhost condition, tobacco and $N$. benthamiana plants were transformed with the $p 23-\mathrm{T} 36$ or $p 23$-tr constructs. Nicotiana spp. are nonhost for CTV; however, whereas $N$. benthamiana protoplasts support virus replication, protoplasts of $N$. tabacum do not (Albiach-Marti et al. 2004; Navas-Castillo et al. 1997). Transgenic plants of N. tabacum (22 expressing $p 23$-T36 and 16 expressing $p 23$-tr) and $N$. benthamiana (34 expressing p23-T36 and 17 expressing p23-tr) were generated and grown in the greenhouse. Western blot analysis showed the accumulation of p23 in all Nicotiana plants transformed with $p 23-\mathrm{T} 36$ that exhibited normal phenotypes and developed as nontransformed controls (Fig. 6E; data not shown). This indicated that p23 interferes with plant development only in citrus species and relatives.

\section{DISCUSSION}

In this study, we have analyzed the effect of the ectopic expression of the CTV p23 protein in transgenic citrus species and relatives and in CTV nonhost Nicotiana spp. The p23 protein accumulation, irrespective of the pathogenicity of the CTV strain (T36 or T317) from which the p23 gene was obtained, was associated closely with the altered phenotype resembling CTV symptoms in Mexican lime, whereas p23 was barely detectable in transgenic sour, sweet, and trifoliate orange showing similar phenotypes; in these three latter species, symptom intensity correlated with the levels of $p 23$ transcripts. In contrast, p23 accumulation in transgenic Nicotiana nonhost species did not incite developmental changes, indicating that $p 23$-induced aberrations are host-specific. These results suggest that p23 is a major pathogenicity factor of CTV that induces 


\section{SwO SO SwO Pt Nb Nt Pt-tr $\stackrel{N}{1} \stackrel{N b}{1}$

$\begin{array}{llllllllllllllll}C & 9 & 19 & 11 & 1 & 32 & 5 & 19 & 9 & 5 & 20 & 1 & 4 & 1 & 2 & C\end{array}$
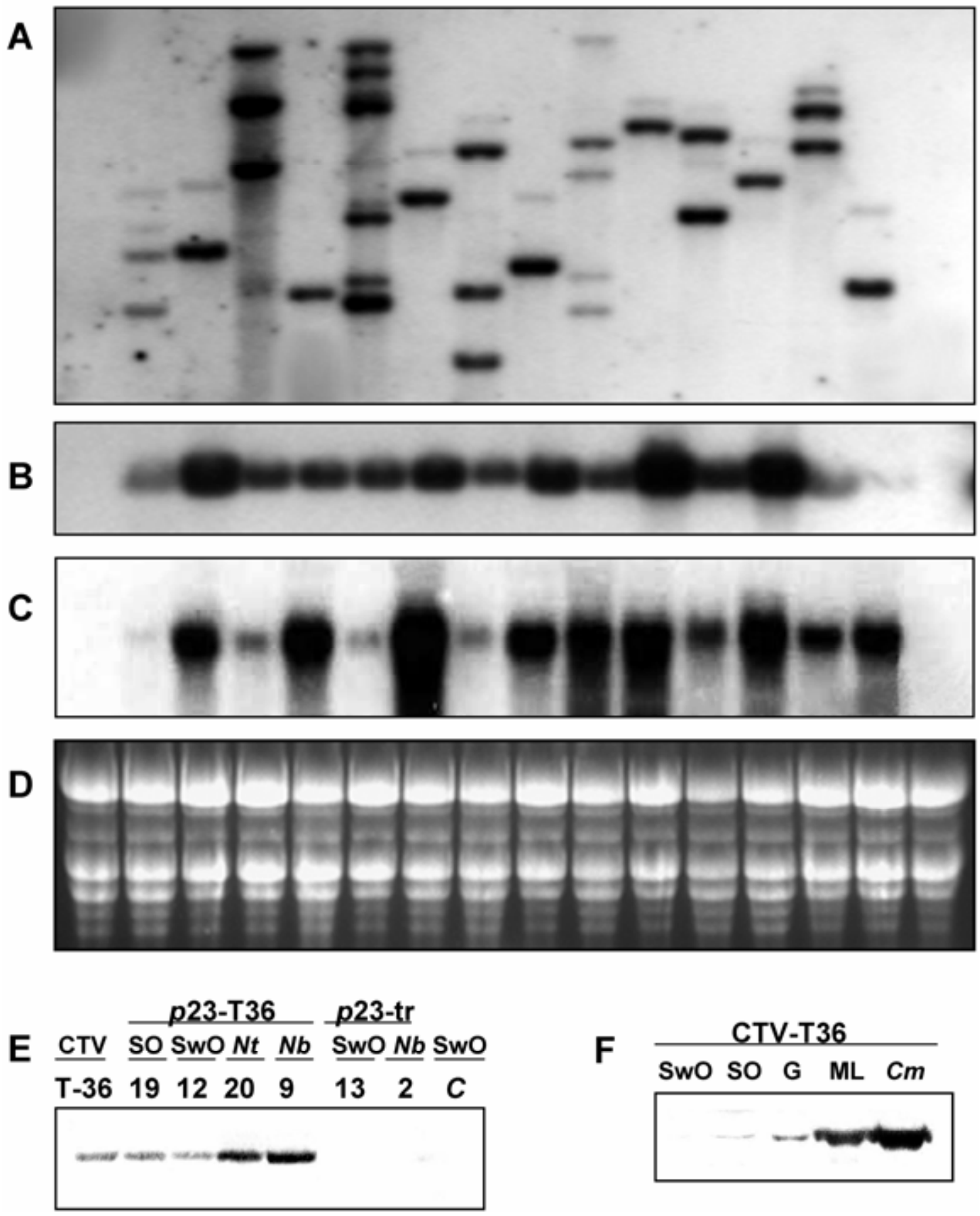

Fig. 6. Integration and transcription of Citrus tristeza virus (CTV) p23 gene in transgenic plants, and accumulation of p23 protein in transgenic and in nontransformed citrus plants inoculated with CTV. A through D, Southern and Northern blot hybridizations of sour orange (SO), sweet orange (SwO), trifoliate orange (Pt), Nicotiana benthamiana $(\mathrm{Nb})$, and $N$. tabacum $(\mathrm{Nt})$ transformed with the p23-T36 gene (lines SO 9 and 19, SwO 11 and 1, Pt 32 and 5, $N b 19$ and 9, and $N t 5$ and 20), or with a truncated version $p 23-\operatorname{tr}$ (lines $P t$-tr 1 and 4, $N b$-tr 1, and $N t$-tr 2), and $\mathbf{C}$, nontransformed SwO and $N b$ controls. DNA was digested with A, EcoRI, which cuts once the T-DNA near the left border, or with B, HindIII, which excises the expression cassette. C, Total RNA from transgenic plants was separated by electrophoresis on a formaldehyde-agarose gel and transferred to a nylon membrane. D, Ethidium bromide staining of the RNA gel showing that equivalent amounts of RNA were loaded in the lanes. A, B, and $\mathbf{C}$, Membranes were probed with a digoxigenin-labeled fragment of the $p 23$ coding region. E, Western blot analysis of SO, SwO, $N t$, and $N b$ transgenic plants carrying the $p 23$-T36 or the $p 23$-tr genes. Numbers refer to the transgenic lines, CTV T-36 to a nontransgenic lime infected by CTV-T36, and $C$ to a nontransformed sweet orange control. F, Accumulation of p23 protein in leaves from CTV-infected citrus plants. Total protein extracted from CTV-T36-infected SwO, SO, grapefruit (G), Mexican lime (ML), and $C$. macrophylla $(\mathrm{Cm})$ plants was separated by electrophoresis in a sodium dodecyl sulfate polyacrylamide gel, transferred to a nitrocellulose membrane, and probed with a CTV p23 antiserum. Each lane was loaded with $20 \mu \mathrm{g}$ of total protein quantified by Bradford analysis. 
phenotypic alterations by interfering with some host developmental processes.

Clues about the underlying mechanism have come from the discovery of RNA silencing as a host resistance strategy, whereby virus gene expression is suppressed by sequence-specific degradation of viral RNA (Chapman et al. 2004; Moissiard and Voinnet 2004; Silhavy and Burgyan 2004). This degradation is triggered by double-stranded RNA generated during virus replication (Ratcliff et al. 1997, 1999). Viruses have developed a counter defense by encoding specific proteins that act as silencing suppressors (Anandalakshmi et al. 1998; Brigneti et al. 1998; Kasschau and Carrington 1998). Virus mutants that lack functional suppressors accumulate at low levels and often are restricted to inoculated cells or leaves (Havelda et al. 2003; Himber et al. 2003; Kasschau and Carrington 2001; Qiu et al. 2002; Silhavy et al. 2002; Voinnet et al. 1999; Yelina et al. 2002). Moreover, transgenic expression of silencing suppressors in herbaceous model plants, mainly Arabidopsis thaliana and $N$. benthamiana, often produces developmental abnormalities that, in some cases, resemble viral symptoms (Chapman et al. 2004; Dunoyer et al. 2004; Silhavy et al. 2002; Van der Wilk et al. 1997). Recently, an explanation has been provided for the developmental defects induced in A. thaliana by the transgenic expression of the P1/HC-Pro silencing suppressor of Turnip mosaic virus (TuMV): overexpression of this protein interferes with the microRNAs (miRNAs) guiding the cleavage of mRNAs that code for transcription factors, thus leading to the ectopic expression of these mRNAs (Kasschau et al. 2003). The similarity between CTV symptoms and the alterations induced by ectopic expression of CTV-p23 in citrus hosts, the recent characterization of p23 as silencing suppressor in $N$. benthamiana and N. tabacum (Lu et al. 2004), and its RNA-binding properties (López et al. 2000) suggest that p23 also could exert its effects through a parallel miRNA-mediated mechanism in the CTV natural woody hosts. However, we cannot exclude that symptom induction by p23 might occur through an alternative mechanism.

Phylogenetic analysis of the predominant sequence variants of the $p 23$ gene from $18 \mathrm{CTV}$ isolates with different pathogenicity in several indicators has revealed that mild and severe strains can be separated into different groups (Sambade et al. 2003), suggesting that symptom intensity depends on the p23 sequence. Although this is in apparent contradiction to the results here reported showing that CTV-like symptoms induced by $p 23$-transgenes in lime plants are independent of the CTV source strain they come from, there are important differences in both experimental approaches; namely, p23 expression is under the control of a constitutive strong promoter in the transgenic plants whereas, in CTV-infected plants, a viral promoter regulates expression of this protein. The most direct interpretation of our present results is that the accumulation in transgenic limes of p23 over a certain threshold incites the CTVlike symptoms regardless of the mild or severe origin of the transgene. Indeed, the intense developmental aberrations in lime plants correlated with p23 levels and were not affected by CTV infection in the early stages. Whether the intensity of symptom incited by different severe and mild CTV isolates in nontransgenic plants can be correlated with the expressed level of $\mathrm{p} 23$ remains to be studied.

A strategy to test the role of certain viral proteins as pathogenicity factors has been to make these proteins dysfunctional by mutation, to alleviate their expression from the viral genome, or to substitute them with a homologue from a related virus (Havelda et al. 2003; Himber et al. 2003; Kasschau and Carrington, 2001; Li et al. 1999; Yelina et al. 2002). Unfortunately, this cannot be done with p23 because it is CTV specific and essential for virus replication (Satyanarayana et al. 1999).
To circumvent this limitation, we have compared the ectopic expression of p23 in other citrus species and relatives with different CTV susceptibility: sweet, sour, and trifoliate orange. Although CTV-T36 causes symptomless infection in sweet orange, transgenic expression of p23-T36 induced leaf symptoms resembling those produced by very severe CTV strains in this host. Similarly, CTV-T36 incites in sour orange seedling yellows and stunting but not the vein clearing and epinasty observed in transgenic plants expressing p23-T36. Finally, morphological alterations caused by the ectopic expression of p23 in trifoliate orange were somehow unexpected because this species is resistant to CTV infection. However, CTV is able to replicate in trifoliate orange protoplasts as efficiently as in sweet orange protoplasts, suggesting that resistance results from a defect on virus movement (Albiach-Marti et al. 2004). Interestingly, trifoliate orange genotypes lacking the markers associated with the CTV resistance locus can be infected systemically by CTV and display leaf symptoms similar to those here observed in the $p 23$-transgenic trifoliate orange (Broadbent et al. 2000; P. Broadbent and D. Hailstones, personal communication).

Although p23 overexpression led occasionally to necrosis and plant death in Mexican lime, this deleterious effect was more generalized in sweet, sour, and trifoliate orange, in which high levels of the transcript, but not of the protein, were observed. Reduced accumulation in transgenic plants of other viral pathogenicity factors has been reported before (Silhavy et al. 2002; Van der Wilk et al. 1997) and interpreted as the consequence of rapid degradation of these proteins due to their toxicity. This view is supported in p23-transgenic sweet, sour, and trifoliate orange plants by i) the low transformation or regeneration efficiencies, ii) the high ratio of dead plants after showing very severe developmental aberrations, and iii) the alternating flushes with and without CTV-like leaf symptoms. Differential accumulation of p23 also was observed after CTV infection of nontransgenic citrus hosts with distinct viral susceptibility; p23 levels were high in the CTV-sensitive Mexican lime and C. macrophylla and were negligible in sweet and sour orange, thus reinforcing the notion that p23 appears to be toxic for the latter two species. In contrast, despite p23 being a silencing suppressor in N. benthamiana and N. tabacum (Lu et al. 2004), it accumulates efficiently in transgenic Nicotiana spp. (grown in the same environmental conditions) without concurrent aberrations, thus indicating that the miRNA-mediated developmental and the siRNA-mediated defense pathways are only partially overlapping, as previously described in Arabidopsis spp. (Dunoyer et al. 2004). These results also discard that p23 may follow a molecular mechanism similar to that of the p19 from tombusviruses, because this silencing suppressor, despite some host-dependent effects for pathogenicity (Chu et al. 2000), operates through siRNA sequestration and, therefore, exerts its effects in a broad range of organisms, including human and Drosophila cells (Dunoyer et al. 2004; Lakatos et al. 2004). The particular toxicity of p23 for citrus and relatives suggests the involvement of a citrus-specific factor absent in Nicotiana spp.

One of the most important CTV effects is the decline of the majority of citrus cultivars grafted on sour orange, which has caused the death of millions of trees propagated on this rootstock (Bar-Joseph et al. 1989). Virus infection in the scion causes phloem necrosis on the sour orange rootstock immediately below the bud union, leading successively to girdling, depletion of starch reserves in the rootstock, and tree decline (Lee and Bar-Joseph 2000). This could result from p23 downloading from the CTV-infected scion into the sour orange rootstock, which is highly sensitive to the accumulation of this protein. Intriguingly, sweet orange also is highly sensitive to 
p23 accumulation but, when used as a rootstock, infected trees do not decline. However, whereas CTV usually reaches high titers in sweet orange, most virus strains are barely detectable and unevenly distributed in sour orange. Mapping p23 regions involved in CTV pathogenesis and working out the host developmental genes that likely become overexpressed in $p 23$-transgenic citrus plants may shed light on the molecular basis of symptom expression and help developing strategies to control CTV-induced damage. Moreover, the recent report of two additional silencing suppressors encoded in the CTV genome $(\mathrm{Lu}$ et al., 2004) supports the existence of pathogenicity determinants other than $\mathrm{p} 23$.

\section{MATERIAL AND METHODS}

\section{Virus strains and recombinant plasmids.}

CTV-T317 and -T305 isolates are part of the collection of CTV isolates maintained at the Instituto Valenciano de Investigaciones Agrarias (Moncada). T317 induces only mild vein clearing in Mexican lime, whereas T305 causes severe symptoms that include vein clearing, leaf distortion, stem pitting, and marked stunting (Moreno et al. 1993). The CTV-T36 used in this work, derived from an infectious cDNA clone (Satyanarayana et al. 2001), was provided by W. O. Dawson (CREC, Lake Alfred, FL) and causes vein clearing, stem pitting, stunting, and leaf cupping in Mexican lime.

The $p 23$ T317 full-length cDNA was obtained by RT with Superscript II $\mathrm{RnaseH}^{-}$reverse transcriptase (Invitrogen) and PCR amplification with $P f u$ DNA polymerase (Stratagene). The sense and antisense primers were RF-266 (5'-CTTGGAT CCATGGATGATACTAGCGG-3') and RF-168 (5'-CTT $\underline{\text { GGAT }}$ CCTCAGATGAAGTGGTGTTC-3'), containing BamHI sites (underlined) to facilitate cloning, and start and stop codons (in bold), respectively. After BamHI digestion, the cDNA was cloned in pMOG180, between the 35S promoter of Cauliflower mosaic virus and the nopaline synthase terminator (nos-ter). This expression cassette was digested with HindIII and subcloned in the corresponding site of the binary plasmid pBin19sgfp between the marker cassettes nos-pro/nptII/nos-ter and 35S-pro/sgfp/nos-ter (Fig. 1B). The resulting plasmid, pBin19p23-T317, was electroporated into the disarmed Agrobacterium tumefaciens EHA105. Construction of pBin19-p23-T36 and pBin19-p23-tr has been described before (Ghorbel et al. 2001) (Fig. 1B).

\section{Plant transformation.}

For transformation, 4- to 12-month-old greenhouse-grown seedlings of Mexican lime (C. aurantifolia (Christm.) Swing.), sweet orange (C. sinensis (L.) Osb., cv. Pineapple), and sour orange (C. aurantium L., cv. Sevillano) and 5-week-old seedlings of trifoliate orange (Poncirus trifoliata (L.) Raf.) cv. Burjasot grown in vitro, were used. Internodal segments of Mexican lime, sweet orange, and sour orange, and epicotyl segments of trifoliate orange (1 cm long) were transformed with $A$. tumefaciens EHA 105 carrying pBin19-p23-T36, pBin19-p23T317, pBin19-p23-tr, or pBin19-sgfp (Peña et al. 2003). Shoots regenerating in a medium containing kanamycin (100 $\mathrm{mg} / \mathrm{liter}$ ) were examined periodically for GFP expression under a stereomicroscope with a Leica fluorescence module. Those shoots exhibiting bright green fluorescence were excised and grafted in vitro on Troyer citrange $(C$. sinensis $\times P$. trifoliata) seedlings (Peña and Navarro 1999). Integration of $p 23$ and $g f p$ transgenes was confirmed by PCR with appropriate primers (Ghorbel et al. 1999, 2001), and PCR-positive plantlets were grafted on vigorous rough lemon (C. jambhiri Lush) seedlings in the greenhouse (day and night temperatures of 26 and $18^{\circ} \mathrm{C}$, respectively).
Leaf disks from $N$. tabacum cv. SR1 and N. benthamiana plants were transformed essentially as described (Horsch et al. 1985) with A. tumefaciens EHA105 harboring pBin19-p23T36 or pBin19-p23-tr. Shoots regenerating and rooting in a kanamycin containing medium were transplanted to soil and transferred to the greenhouse (day and night temperatures of 26 and $18^{\circ} \mathrm{C}$, respectively).

\section{Southern, Northern, and Western blot analyses.}

DNA was extracted from citrus and Nicotiana leaves (Dellaporta et al. 1983) and aliquots $(20 \mu \mathrm{g})$ were digested with HindIII, which excises the $p 23$-derived expression cassettes, or with EcoRI, which cuts the T-DNAs once near the left border (Fig. 1B). After electrophoresis in 1\% agarose gels, the DNA was blotted onto a nylon membrane, fixed by UV irradiation, and probed with a digoxigenin-labeled fragment of the $p 23$ coding region (prepared by PCR) according to the manufacturer's instructions (Roche Diagnostics, Branchburg, NJ, U.S.A.), and detected by chemiluminescence with the CSPDStar substrate (Tropix, Bedford, MA, U.S.A.).

Total leaf RNA from transgenic Nicotiana and citrus plants was extracted with buffer-saturated phenol and then fractionated with $2 \mathrm{M} \mathrm{LiCl}$ (Carpenter and Simon 1998). Northern blot analysis was performed as described (Ghorbel et al. 2001), staining the gels with ethidium bromide prior to and after blot transfer to ensure equal loading and complete transfer of the ribosomal RNA marker.

Leaf protein extracts for Western blot analysis were obtained with $100 \mathrm{mM}$ Tris- $\mathrm{HCl}, \mathrm{pH} 6.8$, containing $0.3 \% \quad \beta$-mercaptoethanol and $1 \mathrm{mM}$ phenyl-methyl-sulfonyl fluoride, and then quantified with the Protein Assay Dye Reagent (Bio-Rad, Hercules, CA, U.S.A.) using bovine serum albumin as standard (Bradford 1976). Protein extracts $(20 \mu \mathrm{g})$ were electrophoresed in $15 \%$ sodium dodecyl sulfate polyacrylamide gels, electroblotted onto nitrocellulose membranes, and probed with a 1:7500 dilution of an antiserum against p23 (Ghorbel et al. 2001). Binding of the antibody was detected with goat antirabbit immunoglobulin $\mathrm{G}$ conjugated with alkaline phosphatase (Promega Corp., Madison, WI, U.S.A.) and visualized with nitroblue tetrazolium and 5-bromo-4-chloro-3-indolyl phosphate. Extracts from $p 23$-tr transgenic leaves and from CTV-infected citrus leaves were used as negative and positive controls, respectively.

\section{Inoculations, ELISA, and RT-PCR analyses.}

Four buds from $p 23-\mathrm{T} 36-3,-41$, and -49 transgenic Mexican limes and from a control line transformed with the empty vector were propagated onto Carrizo citrange rootstock and, when the lime shoots were 30 to $40 \mathrm{~cm}$ long, they were graft inoculated in the rootstock with a CTV-T36 clonal strain (Satyanarayana et al. 2001). Nine buds of trifoliate orange cv. Burjasot were propagated on rough lemon rootstocks and six were graft inoculated with CTV-T36 as described above, with the other three being left as control.

Virus accumulation in successive flushes was estimated by DAS-ELISA using a pool of six to seven leaves collected from each plant and the monoclonal antibodies 3DF1 + 3CA5 (Cambra et al. 1990). Virus RNA was detected by RT-PCR amplification using total RNA (Carpenter and Simon 1998) and the CTV 3'-UTR-specific primers (Domínguez et al. 2002).

\section{ACKNOWLEDGMENTS}

We thank M. Roose (Riverside, CA, U.S.A.) for providing SSR markers near the CTV-resistance locus of trifoliate orange, O. Olivares for helping with the SSR analysis, W. O. Dawson for the CTV T36 clonal strain, and P. Broadbent and D. Hailstones for providing unpublished information. We 
also thank J. A. Pina, M. T. Gorris, and J. Juárez for their excellent technical assistance. This research was supported by grant AGL2003-01644 funded by CICYT, Ministerio de Ciencia y Tecnología, and by grants to $\mathrm{I}+\mathrm{D}+\mathrm{I}$ groups GRUPOS 03/219 and 03/221 (IVIA), and 03/064 (IBMCP) from the Generalitat Valenciana.

\section{LITERATURE CITED}

Albiach-Marti, M. R., Grosser, J. W., Gowda, S., Mawassi, M., Satyanarayana, T., Garnsey, S. M., and Dawson, W. O. 2004. Citrus tristeza virus replicates and forms infectious virions in protoplasts of resistant citrus relatives. Mol. Breed. 14:117-128.

Anandalakshmi, R., Pruss, G. J., Ge, X., Marathe, R., Mallory, A. C., Smith, T. H., and Vance, V. B. 1998. A viral suppressor of gene silencing in plants. Proc. Nat. Acad. Sci. U.S.A. 95:13079-13084.

Bar-Joseph, M., Marcus, R., and Lee, R. F. 1989. The continuous challenge of Citrus tristeza virus control. Annu. Rev. Phytopathol. 27:291-316.

Bradford, M. M. 1976. A rapid and sensitive method for the quantitation of microgram quantities of protein utilizing the principle of protein-dye binding. Anal. Biochem. 72:248-254.

Brigneti, G., Voinnet, O., Li, W. X., Ji, L. H., Ding, S. W., and Baulcombe, D. C. 1998. Viral pathogenicity determinants are suppressors of transgene silencing in Nicotiana benthamiana. EMBO (Eur. Mol. Biol. Organ.) J. 17:6739-6746.

Broadbent, P., Sykes, S. R., Bevington, K. B., Chen Zhusheng, Hailstones, D., and Lewis, W. J. 2000. Variance among Poncirus accessions from the People's Republic of China. Pages 209-210 in: Proceedings of the 9th International Society of Citriculture. F. Gmitter and F. S. Davies, eds. International Society of Citriculture, Orlando, FL, U.S.A.

Cambra, M., Garnsey, S. M., Permar, T. A., Henderson, C., Gumpf, D., and Vela, C. 1990. Detection of Citrus tristeza virus (CTV) with a mixture of monoclonal antibodies. Phytopathology 80:1034.

Carpenter, C. D., and Simon, A. E. 1998. Preparation of RNA. Methods Mol. Biol. 82:85-89.

Chapman, E. J., Prokhnevsky, A. I., Gopinath, K., Dolja, V. V., and Carrington, J. C. 2004. Viral RNA silencing suppressors inhibit the microRNA pathway at an intermediate step. Genes Dev. 18:11791186.

Chu, M., Desvoyes, B., Turina, M., Noad, R., and Scholthof, H. B. 2000 Genetic dissection of tomato bushy stunt virus p19-protein-mediated host-dependent symptom induction and systemic invasion. Virology 266:79-87.

Dellaporta, S. L., Wood, J., and Hicks, J. B. 1983. A plant DNA minipreparation: Version II. Plant Mol. Biol. Rep. 4:19-21.

Domínguez, A., Hermoso de Mendoza, A., Guerri, J., Cambra, M., Navarro, L., Moreno, P., and Peña, L. 2002. Pathogen-derived resistance to Citrus tristeza virus (CTV) in transgenic Mexican lime (Citrus aurantifolia (Christ.) Swing.) plants expressing its $p 25$ coat protein gene. Mol. Breed. 10:1-10

Dunoyer, P., Lecellier, C. H., Parizotto, E. A., Himber, C., and Voinnet, O. 2004. Probing the microRNA and small interfering RNA pathways with virus-encoded suppressors of RNA silencing. Plant Cell 16:1235-1250.

Fang, D. Q., and Roose, M. L. 1999. A novel gene conferring Citrus tristeza virus resistance in Citrus maxima (Burm.) Merrill. HortScience 34:334-335

Febres, V. J., Ashoulin, L., Mawassi, M., Frank, A., Bar-Joseph, M., Manjunath, K. L., Lee, R. F., and Niblett, C. L. 1996. The p27 protein is present at one end of Citrus tristeza virus particles. Phytopathology 86:1331-1335.

Fraser, L. 1952. Seedling yellows, an unreported virus disease of citrus. Agric. Gaz. N. S. W. 63:125-131.

Garnsey, S. M., Su, H. J., and Tsai, M. C. 1996. Differential susceptibility of pummelo and Swingle citrumelo to isolates of Citrus tristeza virus. Pages 138-146 in: Proceedings of the 13th Conference of the International Organization of Citrus Virology J. V. da Graça, P. Moreno, and R. K. Yokomi, eds. IOCV, Riverside, CA.

Ghorbel, R., Juárez, J., Navarro, L., and Peña, L. 1999. Green fluorescent protein as a screenable marker to increase the efficiency of generating transgenic woody fruit plants. Theor. Appl. Genet. 99:350-358.

Ghorbel, R., López, C., Fagoaga, C., Moreno, P., Navarro, L. Flores, R., and Peña, L. 2001. Transgenic citrus plants expressing the Citrus tristeza virus p23 protein exhibit viral-like symptoms. Mol. Plant Pathol. 2:27-36.

Gowda, S., Satyanarayana, T., Davis, C. L., Navas-Castillo, J., AlbiachMartí, M. R., Mawassi, M., Valkov, N., Bar-Joseph, M., Moreno, P., and Dawson, W. O. 2000. The p20 gene product of Citrus tristeza virus accumulates in the amorphous inclusion bodies. Virology 274:246-254.

Havelda, Z., Hornyik, C., Crescenzi, A., and Burgyán J. 2003. In situ characterization of Cymbidium Ringspot Tombusvirus infection-induced posttranscriptional gene silencing in Nicotiana benthamiana. J. Virol. 77:6082-6086.

Hilf, M. E., Karasev, A. V., Pappu, H. R., Gumpf, D. J., Niblett, C. L., and Garnsey, S. M. 1995. Characterization of Citrus tristeza virus subgenomic RNAs in infected tissue. Virology 208:576-582.

Himber, C., Dunoyer, P., Moissiard, G., Ritzenthaler, C., and Voinnet, O. 2003. Transitivity-dependent and independent cell-to-cell movement of RNA silencing. EMBO (Eur. Mol. Biol. Organ.) J. 22:4523-4533.

Horsch, R. B., Fry, J. E., Hoffmann, N. L., Eichholtz, D., Rogers, S. G., and Fraley, R. T. 1985. A simple and general method for transferring genes into plants. Science 227:1229-1231.

Karasev, A. V., Boyko, V. P., Gowda, S., Nikolaeva, O. V., Hilf, M. E., Koonin, E. V., Niblett, C. L., Cline, K., Gumpf, D. J., Lee, R. F., Garnsey, S. M., Lewandovsky, D. J., and Dawson, W. O. 1995. Complete sequence of the Citrus tristeza virus RNA genome. Virology 208:511-520.

Kasschau, K. D., and Carrington, J. C. 1998. A counterdefensive strategy of plant viruses: Suppression of posttranscriptional gene silencing. Cell 95:461-470.

Kasschau, K. D., and Carrington, J. C. 2001. Long-distance movement and replication maintenance functions correlate with silencing suppression activity of potyviral HC-Pro. Virology 285:71-81.

Kasschau, K. D., Xie, Z., Allen, E., Llave, C., Chapman, E. J., Krizan, K. A., and Carrington, J. C. 2003. P1/HC-Pro, a viral suppressor of RNA silencing, interferes with Arabidopsis development and miRNA function. Develop. Cell 4:205-217.

Lakatos, L., Szittya, G., Silhavy, D., and Burgyan, J. 2004. Molecular mechanism of RNA silencing suppression mediated by 19 protein of tombusviruses. EMBO (Eur. Mol. Biol. Organ.) J. 23:876-884.

Lee, R. F., and Bar-Joseph, M. 2000. Tristeza. Pages 61-63 in: Compendium of Citrus Diseases, 2nd ed. L. W. Timmer, S. M. Garnsey, and J. H. Graham, eds. American Phytopathological Society, St. Paul, MN, U.S.A.

Li, H., Lucy, A. P., Guo, H. S. Li, W. X., Ji, L. H., Wong, S. M., and Ding, S. W. 1999. Strong host resistance targeted against a viral suppressor of the plant gene silencing defense mechanism. EMBO (Eur. Mol. Biol. Organ.) J. 18:2683-2691

López, C., Navas-Castillo, J., Gowda, S., Moreno, P., and Flores, R. 2000. The $23 \mathrm{kDa}$ protein coded by the 3'-terminal gene of Citrus tristeza virus is an RNA-binding protein. Virology 269:462-470.

Lu, R., Folimonov, A., Shintaku, M., Li, W.-X., Falk, B. W., Dawson, W. O., and Ding, S. W. 2004. Three distinct suppressors of RNA silencing encoded by a $20-\mathrm{kb}$ viral RNA genome. Proc. Natl. Acad. Sci. U.S.A. $101: 15742-15747$

Mestre, P. F., Asins, M. J., Pina, J. A., and Navarro, L. 1997. Efficient search for new resistant genotypes to the citrus tristeza closterovirus in the orange subfamily Aurantioideae. Theor. Appl. Genet. 95:1282-1288.

Moissiard, G., and Voinnet, O. 2004. Viral suppression of RNA silencing in plants. Mol. Plant Pathol. 5:71-82.

Moreno, P. Guerri, J., Ballester-Olmos, J. F., Albiach, R., and Martinez M. E. 1993. Separation and interference of strains from a citrus tristeza virus isolate evidenced by biological activity and double stranded RNA (dsRNA) analysis. Plant Pathol. 42:35-41.

Navas-Castillo, J., Albiach-Marti, M. R., Gowda, S., Hilf, M. E., Garnsey, S. M., and Dawson, W. O. 1997. Kinetics of accumulation of Citrus tristeza virus RNAs. Virology 228:92-97.

Pappu, S. S., Febres, V. V., Pappu, H. R., Lee, R. F., and Niblett, C. L. 1997. Characterization of the $3^{\prime}$ proximal gene of the Citrus tristeza Closterovirus genome. Virus Res. 47:51-57.

Peña, L., and Navarro, L. 1999. Transgenic Citrus. Pages 39-54 in: Biotechnology in Agriculture and Forestry Volume 44, Transgenic Trees. Y. P. S. Bajaj, ed. Springer-Verlag, Berlin.

Peña, L., Cervera, M., Ghorbel, R., Dominguez, A., Fagoaga, C., Juárez, J., Pina, J. A., and Navarro, L. 2003. Transgenic citrus. Pages 261-282 in: Plant Genetic Engineering Volume 3, Improvement of Commercial Plants-I. R. P. Singh and P. K. Jaiwal, eds. SCI Tech Publishing LLC, Houston, TX, U.S.A

Qiu, W., Park, J. W., and Scholthof, H. B. 2002. Tombusvirus P19-mediated suppression of virus-induced gene silencing is controlled by genetic and dosage features that influence pathogenicity. Mol. PlantMicrobe Interact. 15:269-280.

Ratcliff, F., Harrison, B. D., and Baulcombe, D. C. 1997. A similarity between viral defense and gene silencing in plants. Science 276:1558-1560.

Ratcliff, F. MacFarlane, S., and Baulcombe, D. C. 1999. Gene silencing without DNA. RNA-mediated cross-protection between viruses. Plant Cell 11:1207-1216.

Reed, J. C., Kasschau, K. D., Prokhnevsky, A. I., Gopinath, K., Pogue, G. P., Carrington, J. C., and Dolja, V. V. 2003. Suppressor of RNA silencing encoded by Beet yellows virus. Virology 306:203-209.

Roistacher N., and Moreno, P. 1991. The worldwide threat from destructive isolates of Citrus tristeza virus-A review. Pages 7-19 in: Proceed- 
ings of the 11th Conference of the International Organization of Virology R. H. Brlansky, R. F. Lee, and L. W. Timmer, eds. International Organization of Citrus Virologists, Riverside, CA, U.S.A.

Sambade, A., López, C., Rubio, L., Flores R., Guerri, J., and Moreno, P. 2003. Polymorphism of a specific region in gene p23 of Citrus tristeza virus allows discrimination between mild and severe isolates. Arch. Virol. 148:2325-2340.

Satyanarayana, T., Bar-Joseph, M., Mawassi, M., Albiach-Marti, M. R., Ayllón, M. A., Gowda, S., Hilf, M. E., Moreno, P., Garnsey, S. M., and Dawson, W. O. 2001. Amplification of Citrus tristeza virus from a cDNA clone and infection of citrus trees. Virology 280:87-96.

Satyanarayana, T., Gowda, S., Ayllón, M. A., Albiach-Marti, M. R. Rabindran, S., and Dawson, W. O. 2002. The p23 protein of Citrus tristeza virus controls asymmetrical RNA accumulation. J. Virol. 76:473-483.

Satyanarayana, T., Gowda, S., Ayllón, M. A., and Dawson, W. O. 2004 Closterovirus bipolar virion: Evidence for initiation of assembly by minor coat protein and its restriction to the genomic RNA 5' region. Proc. Natl. Acad. Sci. U.S.A. 101:799-804.

Satyanarayana, T., Gowda, S., Boyko, V. P., Albiach-Marti, M. R. Mawassi, M., Navas-Castillo, J., Karasev, A. V., Dolja, V., Hilf, M. E., Lewandowski, D. J., Moreno P., Bar-Joseph M., Garnsey, S. M., and Dawson, W. O. 1999. An engineered Closterovirus RNA replicon and analysis of heterologous terminal sequences for replication. Proc. Natl. Acad. Sci. U.S.A. 96:7433-7438.

Satyanarayana, T., Gowda, S., Mawassi, M., Albiach-Marti, M. R., Ayllón, M. A., Robertson, C., Garnsey, S. M., and Dawson, W. O. 2000. Clos- terovirus encoded HSP70 homolog and p61 in addition to both coat proteins function in efficient virion assembly. Virology 278:253-265.

Silhavy, D., and Burgyán, J. 2004. Effects and side-effects of viral RNA silencing suppressors on short RNAs. Trends Plant Sci. 9:76-83.

Silhavy, D., Molnár, A., Lucioli, A., Szittya, G., Hornyik, C., Tavazza, M., and Burgyán, J. 2002. A viral protein suppresses RNA silencing and binds silencing-generated, 21- to 25-nucleotide double-stranded RNAs. EMBO (Eur. Mol. Biol. Organ.) J. 21:3070-3080.

Van der Wilk, F., Houterman, P., Molthoff, J., Hans, F., Dekker, B., van den Heuvel, J., Huttinga, H., and Goldbach, R. 1997. Expression of the Potato leafroll virus ORF0 induces viral-disease-like symptoms in transgenic potato plants. Mol. Plant-Microbe Interact. 10:153-159.

Voinnet, O., Pinto, Y. M., and Baulcombe, D. C. 1999. Suppression of gene silencing: A general strategy used by diverse DNA and RNA viruses of plants. Proc. Natl. Acad. Sci. U.S.A. 96:14147-14152.

Yang, Z.-N., Ye, X.-R., Molina, J., Roose, M. L., and Mirkov, T. E. 2003. Sequence analysis of a 282-kilobase region surrounding the Citrus tristeza virus resistance gene (Ctv) locus in Poncirus trifoliata L. Raf. Plant Physiol. 131:482-492.

Yelina, N. E., Savenok, E. I., Solovyev, A. G., Morozov, S. Y., and Valkonen, J. P. 2002. Long-distance movement, virulence, and RNA silencing suppression controlled by a single protein in Hordei-and Potyviruses: Complementary functions between virus families. J. Virol. 76:12981-12991.

Yoshida, T. 1996. Graft compatibility of citrus with plants in the Aurantiodeae and their susceptibility to Citrus tristeza virus. Plant Dis. 80:414414. 